$\xi=-1$

\title{
Transforming Mosques Into a Containment Space During Natural Disasters; Browsing Through Recent Publications
}

\author{
Hayder Jawad Shakir Haraty ${ }^{1}$, Mohammad Yazah Mat Raschid ${ }^{2}$ and Nangkula Utaberta ${ }^{3}$ \\ ${ }^{1,2,3}$ Department of Architecture, Faculty of Design and Architecture, Universiti Putra Malaysia, 43400 UPM Serdang, Malaysia \\ *Corresponding author E-mail: hayderharaty@gmail.com; haidar_jwd@hotmail.com
}

\begin{abstract}
Mosques around the world have been serving the Muslim community for religious and social purposes since the beginning of Islam. Mosques have played an important role to educate and create a peaceful yet proper cosmos for its visitors. However, nowadays, mosques are not only used for its educational component, but on occasion have been transformed into places to serve multi-ethnic and multireligious communities during natural disasters. This paper is an attempt to surf through the recent publications that discuss natural disasters and the containment of such incidents. Four case studies have been presented to draw a picture of a mosque's role before, during and after natural disasters. Although many researchers have investigated this role, there still is an urgent need to understand the several examples of cases globally and the issues the researchers have dealt with in such incidents. Selected papers have been reviewed to study the conclusions found in the most recent publications in this field. The aim of this paper is to find out the missing aspects and the gap in the literature for the purpose of future studies and designs.
\end{abstract}

Keywords: Natural disasters; Transformed spaces; Containment spaces; Mosque's design

\section{Introduction}

Environmental hazards such as hydro-meteorological ones (floods, typhoons, droughts etc.) are increasing in many countries in Asia and several other countries. Such natural hazards have caused many deaths and disasters such as earthquakes that have also caused much damage on the infrastructure and buildings in many cities [1]. Additionally, flood ratios are increasingly seen as one of the most fatal disasters which have affected many people; especially in urban areas [2]. It is extremely important to reduce the number of deadly hazards and enhance building disaster resilience among the communities.

There have been several transformational methods in dealing with natural disasters and their impacts. In Indonesia, for example, the Indian Ocean Tsunami in 2004, saw the turning point in trying to reduce and manage the impact of such horrific disasters on an international level. There have been different stages in dealing with such incidents, starting with early warnings or predictions, knowledge and education, reducing the underlying risk factors, and finally, preparedness and response [3]. The governance has transformed from focusing on emergency response after the disaster occurs to more preventive approaches [4].

Another study by Utaberta [5], stated that since the first existence of mosques and during the time of Prophet Mohammad (pbuh), the role of mosques have not been limited to religious purposes nor primarily for worship only. The first mosque, Masjid Nabawee, was built by the Prophet and has stood as a symbol of Islam's greatness until today. The Nabawee mosque was a center of various activities, but over time the role of mosques has changed. The research further explained that the management role during any disaster can take various forms, as seen in Table 1 which shows the different phases.

Although mosques have played an important role during natural disasters by collecting funds and charity (sadaqat), they have also been organizing the community as a place of refuge for those seeking temporary shelter [6]. Mosques, following the Islamic teachings, must always be a place that promotes harmony, peace and goodwill among people. Therefore, during the time of tragedy, Muslims should play an active role within societies and always step up to assist those in need. Mosques have always been constructed to withstand disasters, consequently; it could serve as a good home or shelter during any incident. Mosques can be transformed to accommodate vulnerable communities seeking shelter and be a center of aid coordination [6]. People use the mosque during natural hazards to seek spiritual and psychological composure [1].

In Indonesia, Islamic Relief operation was informally launched since 2000 with the help of local partner through emergency interventions after the financial crises in 1998. By establishing a central office in Jakarta, The Islamic Relief Indonesia (IRI) has signed multiple arrangements to work in ten districts for emergency/disaster intervention activities which is aiming for the whole county in the future. However, Coordination of Humanitarian Affair (OCHA) by the United Nations (UN), has been with OCHA Indonesia to ensure humanitarian coordination to fulfill the needs of vulnerable communities in natural disaster affected areas [6]

Table 1: Phases of the disaster management cycle

\begin{tabular}{|l|l|}
\hline \multicolumn{1}{|c|}{$\begin{array}{c}\text { Role during the initial reaction } \\
\text { and help }\end{array}$} & \multicolumn{1}{c|}{$\begin{array}{c}\text { Role during recovery, reconstruc- } \\
\text { tion and rehabilitation }\end{array}$} \\
\hline $\begin{array}{l}\text { - Benchmark as an early } \\
\text { warning space and forum for } \\
\text { coordinating the response }\end{array}$ & $\begin{array}{l}\text { - To support life } \\
\text { - To support psychosocial, spiritual } \\
\text { healing }\end{array}$ \\
\hline
\end{tabular}

Copyright $\odot 2018$ Authors. This is an open access article distributed under the Creative Commons Attribution License, which permits unrestricted use, distribution, and reproduction in any medium, provided the original work is properly cited. 


\begin{tabular}{l|l}
\hline - rescue aid to ensure the inclu- & - creating resilience of the society \\
sion of vulnerable groups & - A space for community activities \\
- Integrate communities & (e.g., schooling, work together) \\
- Appoint volunteers & \\
- Provide spiritual support & \\
- Become the main center for \\
providing information to the \\
public
\end{tabular}

Historically, during the Ottoman era, the Sultans built the mosque to preserve responsibilities and for maintaining social welfare. In Damascus and elsewhere, the urban city of the Ottoman Empire established mosque complex and other foundation that played a part during the disaster as the source of relief by hosting the displaced people and by also providing food and necessities to thousands in need. Unlike private charities, the waqaf was pious act intrinsically which; therefore, mosques were priorities to restore if damaged due you to the role of offering psychological and physical help to refugees [7].

\section{Aim of Research}

This paper is an attempt to reveal the recent publication that had investigated the role of a mosque as a shelter in an emergency situation and disaster. This paper studies researchers' opinions and the recent cases around the world and Asia specifically. In spite of the several attempts, there has not been a proper study looking at this interesting experience [6].

\section{Kelantan's Flood and the Role of Mosques in Malaysia:}

Kelantan is one of the states in Malaysia that have encountered several flood disasters in the form of flash floods and monsoon floods, which occurs when there is too much irrigation water. The annual issue of floods in the state of Kelantan is mainly due to the topography, consisting of a labyrinth of rivers; the other reason is attributed to the climate and the yearly rainfall [5]. The heavy rains raise the quantity of water on Kelantan's rivers causing floods yearly. In December 2014, the occurrence of heavy rains that descended above normal, caused flooding which was the highest recorded in that year. Furthermore, the state had encountered several floods in the years 1967, 1998, 2004 and 2014 which caused multiple loses in property and lives [8].

On that note, very few interviews have been conducted to fully understand the issues responsible for the flood disasters in Kelantan, Malaysia. It has been stated that after the flood occurred, the transfer area was turned into a cooking place to distribute food to the victims. The main issue was that the volunteers were among the people who did not have the experience to carry out rescue operations. Other issues like communication and preparedness from the authorities were not enough. It was proposed that mosque areas could work as a place of relief during disaster situations [9] It was suggested by YM Raja Samri that the first step during floods is to clean up the mosque and use it to coordinate and assist flood disaster victims. Using the mosque as a center for such activities could unite people and reduce loss as much as possible Table 2 concludes the role of a mosque before and after disasters.

Table 2: The role of Mosques before and after disasters

\begin{tabular}{|l|l|}
\hline $\begin{array}{l}\text { Before Disaster Coordinating } \\
\text { Role }\end{array}$ & $\begin{array}{l}\text { - As a place of worship } \\
\text { - As a place of prayer, especially } \\
\text { the Friday prayers congregation }\end{array}$ \\
\hline $\begin{array}{l}\text { The role of Mosque in Emergen- } \\
\text { cies }\end{array}$ & $\begin{array}{l}\text { - Most of the mosques in the report } \\
\text { submerged during the flood disaster } \\
\text { occurred } \\
\text { - Set up a disaster management } \\
\text { committee members }\end{array}$ \\
\hline $\begin{array}{l}\text { After Disaster Coordinating } \\
\text { Role }\end{array}$ & $\begin{array}{l}\text { - Made as a temporary center } \\
\text { - As a disaster relief collection } \\
\text { center }\end{array}$ \\
\hline
\end{tabular}

As a spirit after the flood disaster recovery (where counseling)

\section{Sri Lanka Tsunami:}

The Indian Ocean tsunami happened on December 26, 2004, resulting in many deaths and loss of property. Some might see it as a paradigmatic case of gift-giving which pushed for unprecedented levels of donation from all around the world [10]. According to many sources, the disaster resulted in many deaths and more than one and half million people were displaced from their homes [11].

Another research by Korf [10] which has published the effort of many around the world in helping out with this tragedy. The publication further explained that Muslims on the south coast suffered major devastation. The country is known for its multi-cultural and multi-religious society, and people rushed to offer help to those in need. The research also showed that after the disaster, mosque became a place for refuge for the displaced, it became a center for material and spiritual relief. Also, hospitals and schools or public buildings played their part in providing a temporarily shelter.

Each location received donations from many different sources and assuredly aid was equally distributed to the people. The mosque particularly ensured that donations were distributed fairly [10] The post-tsunami Sri Lanka showed religious, economic, and political levels in dealing with the tragedy. With regards to the tsunami disaster, mosques showed no exception to those who were in need of help, people rushed from various cultures and religions to find peace under the mosque's roof.

\section{Pakistan's Earthquake:}

A major earthquake shook Pakistan on Saturday, October 8, 2005, at 8:50 a.m. The epicenter of a 7.6 magnitude quake was about 65 miles north-northeast of Islamabad, the country's capital. Approximately 150000 citizens were either killed or injured, three million people lost their home during a time where winter was approaching. Volunteers from Turkey, Jordan, Indonesia, Malaysia, and Taiwan rushed to assist people during this massive tragedy with aid and medical help [12].

Islam is the main religion in Pakistan, people tend to trust in religious institutions and regularly donate to mosques. Furthermore, mosques have always been a source of spiritual, cultural and educational influence on people in Muslim societies. A research by Cheema [13] explored the important role of mosques before and after disasters. The study also explains how mosques can play a part in reconstruction and recovery after such incidents. Moreover, the study argues that every religious institution can have a role during natural disasters by offering spiritual and physical help for displaced people. In the aftermath of the 2005 earthquake in Pakistan, mosques continued to raise funds and send volunteers to help out [14].

In New Zealand, after the earthquake in 2010 and 2011, mosques took a leading role in assisting by fundraising, providing disaster relief and rehabilitation operations in the country. In addition, in the 2011 flood of Pakistan and Australia, the Muslim men and women were called by the imam of the mosque to donate generously as it is highly encouraged by Allah. The mosque also took on the role of promoting awareness during the natural disasters and giving information [15].

\section{Afghanistan Flood Disaster:}

The natural hazard of a flood disaster in Afghanistan occurred in the spring of 1965 in the city of Nimruz (Sistan). Heavy snowfall followed by the air temperature during the spring caused massive 
flow of water through the newly built dam which was meant to protect the province Zabul from floods. Most of the houses that were evacuated had collapsed later on [16]. The flood left around 1000 people homeless and waiting to be relocated to their new city. The concept advised by the governor and designers was to come up with a solution where the mosque centered in the new city and was away from future flood disasters. It can be identified that there were no such shelters for displaced people after a tragedy occurred and most people stayed in tents. However, in 2009, a research book that was published, pointed out the role of the mosque during one of the flood disaster incidents. The mosque was used to warn people of the city of Adrasskan before the arrival of the flood. Citizens of the city were able to escape and no one died [17].

\section{Discussion}

The discussion of this paper is to explore the concept of mosques as a space for Muslims and people of other religions to use during natural disasters. The previous case studies discussed the numerous hazards that have occurred in several countries causing traumas and many deaths among people as well as property loss. Although much effort has been made to avoid and decrease the damage before and after any natural disaster, there have been many evidences shown that the lack of appropriateness in dealing with such traumas. The mosque as an individual unit of peace and spiritual activities, could also be used to deliberate important information and knowledge to Muslims and others. It has been pointed out that governments, authorities and volunteers have been recently paying more attention to this space by applying various tools to be used before and after any disaster. Mosques could be used as a transformed space to aid and offer shelter to displaced people. Prophet Mohammad (pbuh) mentioned that mosques should be built to represent Islam's greatness and not only for worship purposes. Mosques should also be used as an educational hub, to carry out various kinds of activities. Furthermore, mosques can also offer a space for psychological and physical help to refugees by using funds from generous people who are willing to help.

The cases from Malaysia, Sri Lanka, Pakistan, and Afghanistan have shown numerous ways that the mosques have contributed in helping out when natural disasters happen. Hazards are natural disasters which happen yearly due to many reasons. Many countries have showcased different ways in handling those accidents. By knowing about the disaster before it occurs could save many lives as well as increase preparedness.

\section{Conclusion}

Hazards are driven by nature, it could happen anytime, and anywhere, therefore, people should be prepared and aware before any natural disaster occurs even though local governments have relied on technology to measure and predict such disasters. The purpose of this paper is to highlight the importance of mosques in the containment of tragedies in natural disasters, and to introduce the cases where mosques have played or could have before any incident. Additionally, the mosques in the case studies showed their effectiveness in sharing awareness between citizens, educating and offering help to those in need. Natural disasters have caused millions of deaths in the last few decades and will continue to do so in the future. These could be resolved by decreasing the number of loss whether in lives or properties; it could also make people more aware and more prepared.

In spite of the importance of mosques, some have failed to propose an effective way to deal or transform the mosque into an aid space which can be used after a disaster. Some evidence not only from Muslim societies have shown how the imam of mosques and volunteers could assist in several ways by fund raising or offering help to displaced people. Finally, it should be emphasised that some countries like Indonesia have moved forward to produce new methods which can save many lives in the future. The role of mosques has been and will continue to be a center of knowledge and help, spiritually, culturally and physically for all kinds of societies.

\section{Acknowledgement}

The authors wish to acknowledge their gratitude to the anonymous reviewers who gave freely time and effort, constructive recommendations that enhanced the value of this manuscript.

\section{References}

[1] F. Mulyasari and R. Shaw, "The Role of Faith-Based Organizations (FBOs) as Risk Communicators: Case Study of Bandung, West Java," in Disaster Risk Reduction in Indonesia: Progress, Challenges, and Issues, R. Djalante, M. Garschagen, F. Thomalla, and R. Shaw, Eds. Cham: Springer International Publishing, 2017, pp. 377-393.

[2] ADRC, "Natural Disaster Data Book 2009 (An Analytical Overview)," 2011

[3] UNISDR, "Indigenous Knowledge for Disaster Risk Reduction," Indig. Knowl. Disaster Risk Reduct., vol. 97, no. 1, pp. 12-21, 2008.

[4] R. Djalante, M. Garschagen, F. Thomalla, and R. Shaw, Disaster Risk Reduction in Indonesia, 1st ed. Springer International Publishing, 2017.

[5] N. Utaberta and I. Rahayu, "The Role of the Masjid in Disaster Management: Qualitative Data Specifically by Informants Based on their Experiences," Res. J. Fish. Hydrobiol., vol. 11, no. 3, pp. 158-164, 2016.

[6] IRI, UNOCHA, and LPBI NU, "Preliminary Studies of the Potential Role of the Mosque in Disaster Situation in Indonesia: Six Mosques in Two Provinces," 2011.

[7] Y. Ayalon, Natural Disasters in the Ottoman Empire. Cambridge University Press, 2014.

[8] N.Utaberta, M. T. M. Rasdi, N. Spalie, N. A. G. Abdullah, and M.M.Tahir, "Analisis Tipologi Dan Pendekatan Perancangan Masjid Moden,” J. Des. + Built, vol. 1, no. 1, pp. 69-85, 2011.

[9] H. Mortada, Traditional Islamic Principles of Built Environment. London and New York: Al Islamic Principles Of Built Environment Hisham Mortada RoutledgeCurzon, 2003.

[10] B. Korf, S. Habullah, P. Hollenbach, and B. Klem, "The gift of disaster: The commodification of good intentions in post-tsunami Sri Lanka," Disasters, vol. 34, no. 1, pp. 60-77, 2010.

[11] BBC NEWS, "BBC NEWS | World | Asia-Pacific | US presidents in tsunami aid plea," US presidents in tsunami aid plea, 2005. [Online]. Available: http://news.bbc.co.uk/2/hi/asiapacific/4143459.stm\#map.

[12] T. C. Foundation, "2005 Pakistan Earthquake," Buddhist Compassion Relief Tzu Chi Foundation, 2010.

[13] A. R. Cheema, "Exploring the role of the mosque in dealing with disasters: A case study of the 2005 earthquake in Pakistan," Massey University, 2012.

[14] S. Rehman and V. S. Kalra, "Transnationalism from below: initial responses by British Kashmiris to the South Asia earthquake of 2005," Contemp. South Asia, vol. 15, no. 3, pp. 309-323, 2006.

[15] A. R. Cheema, A. Mehmood, and M. Imran, "Learning from the past Analysis of disaster management structures, policies and institutions in Pakistan," Disaster Prev. Manag. An Int. J., vol. 25, no. 4, pp. 449-463, 2016.

[16] A. Breshna, "Shelter for the Homeless after a Flood Disaster Practical Experience in Southwest Afghanistan," Disasters, vol. 12, no. 3, pp. 203-208, 1988.

[17] ICIMOD, Mountain Development Resource Book for Afghanistan. Nepal: The International Centre for Integrated Mountain Development, 2009. 